\title{
Verdensdagen for selvmordsforebygging 10. september 2008
}

vivat

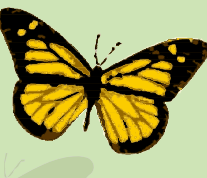

\section{Førstehjelp ved selvmordsfare}

Førstehjelp ved selvmordsfare er et todagers intensivt kurs som retter seg mot alle som i sitt virke kommer i kontakt med selvmords nære mennesker. Kurset har en praktisk, tverrfaglig tilnærming, der deltakerne lærer å oppfatte faresignaler og intervenere i selvmordskriser. Gjennom rollespill, forelesninger, videofilmer og praktiske øvelser får deltakerne ferdighetstrening og større trygghet i møte med mennesker som kan være i selvmordsrisiko.

På kurset lærer man å:

- Fange opp mennesker som har det vondt og som kan være i selvmordsfare

- Stille direkte spørsmål om selvmordstanker

- Hjelpe personen i selvmords fare til å snakke om det som er vanskelig

- Gjøre en enkel risikovurdering

- Lage og iverksette en plan med vedkommende hvor målet er å berge livet

- Bruke lokale ressurser i krisehjelp

Undervisningsprogrammet ble opprettet i 2000 som et av flere tiltak under Handlingsplan mot selvmord, og siden den gang har ca. 14000 deltakere gjennomført kurset. Programmet er finansiert av Helsedirektoratet.

Mer informasjon om planlagte kurs finnes på www.unn.no/vivat Interesserte kan også ta kontakt med VIVAT V/Hans Lander på telefon 77627823 eller e-post:vivat@unn.no

Elin A nita Fadum er stipendiat ved Seksjon for selvmordsforskning og -forebygging (SSFF).

$H$ enning $H$ errestad er nestleder og dr.philos. ved SSFF.

\section{Tenk globalt. Planlegg nasjonalt. Handle lokalt.}

$\AA$ rets motto for $V$ erdensdagen uttrykker ønsket om å utvikle en global bevissthet rundt selvmord som en hyppig årsak til for tidlig død. M ottoet setter fokus på de politiske rammene for det sel vmordsforebyggende arbeidet og peker på behovet for at de mange praktiske forebyggingsprogrammene kan omforme politiske uttal el ser og forskningsresultater til aktiviteter på lokalt nivå.

Verdensdagen for selvmordsforebygging er en internasjonal dag som markeres over hele verden. I N orge er LEVE - Landsforeningen for etterlatte ved selvmord - den nasjonale koordinatoren, og LEV E har arrangementer i alle fylker. Verdensdagen for selvmordsforebygging er støttet av Verdens hel seorganisasjon og er et initiativ fra IA SP (International A ssociation for Suicide Prevention).

LEVE er en frivillig organisasjon som arbeider for at etterlatte ved selvmord skal få støtte og omsorg, og for å forebygge selvmord. LEV E har fylkeslag i alle landets fylker, og du finner informasjon om oss på www.leve.no.

LEV E har nettopp fullført sin første treårsperiode som nasjonal koordinator for Verdensdagen, og det gir oss mulighet til å kikke oss over skulderen og se hva som har skjedd i løpet av perioden 2005-2007, hvor LEVE har arbeidet med å etablere V erdensdagen på landsbasis innad i organisasjonen og utad, som en internasjonal dag som flest mulig har hørt om.

Verdensdagen for selvmordsforebygging 10. september ble markert første gang i N orge i 2004 - den gang av Seksjon for selvmordsfors kning og -forebygging. En håndfull fylkeslag fra LEVE var også med og markerte dagen.

I O slo var det en større, nasjonal markering hvor daværende statsminister Kjell M agne Bondevik, holdt en appell. Fra 2005 overtok LEV E koordineringsansvaret og ansatte en prosjektleder i en $50 \%$ stilling. Dette året hadde alle LEV Es fylkeslag en bidratt med finanisering, både til nasjonal koordinering og til nasjonale og lokale arrangementer.

Tanken om nasjonale markeringer som henvender seg til forskjellige grupper ved å ha en variasjon i uttrykksformene og som i tillegg har en bred tilgjengelighet, har vært vellykket. I 2005 markerte LEV E Verdensdagen i 0 slo med et arrangement i 0 slo Konserthus. I 2006 inviterte LEVE til en kunstutstilling på Rådhusplassen i 0 slo, som markering. H elsedirektoratet har siden starten fikk en overveldende respons. U ten dørsutstillingen involverte både skulptur-, installaca. 800000 mennesker i løpet av de fjorten dager den stod, og samarbei det med kunstnerne gikk knirkefritt. I fjor ble det bestemt at ett fylkeslag skulle stå som arrangør for den nasjonale markeringen. LEVE H ordaland stod for et todelt arrangement i Bergen. 9. september inviterte LEV E til en veldedighetskonsert i G rieghallen med bl.a. M ari Boine, og 10. september var ca. 300 deltakere samlet på den nasjonale fagkonferansen i G rieghallen med temaet Selvmord i alle faser av livet.

Siden 2005 har Verdensdagen mer enn doblet budsj ettet, og de fleste fylkeslagene satser i 2008 på større arrangementer med tydeligere faglig forankring. LEVE har siden 2007 valgt å trykke opp en egen brosjyre til verdensdagen.

A rets nasjonale arrangement vil finne sted i 0 slo i form av en fagkonferanse i $G$ amle Logen 10. september, kl. 9-16. Foredragsholdere vil bli Lars M ehlum, Berit G røholt, Ingeborg R ossow, Ildri Kjølseth og Pål K ristensen. Studenter og medlemmer av LEVE betaler ikke konferanseavgift.

LEV E har også fått midler fra H elsedirektoratet til å utvikle konseptet rundt en helaftens dokumentarfilm med selvmordsforebygging som tema. U tviklingsmidler til dette prosjektet er også gitt fra Scheiblers legat, og arbeidet vil trolig starte før sommeren. En dokumentarfilm vil føye nok et uttrykk til Verdensdagens nasjonale arrangementer og vil forhåpentligvis nå mange nye grupper.

For mer informasjon om aktiviteter lokalt, se www.leve.no under fylkesl agenes egne sider.

Det legges ned atskillige timer frivillig arbeid i Verdensdagen, og vi oppfordrer herved fagmiljøene til å støtte opp om Verdensdagen og aktivitetene i nærmiljøet i forbindel se med 10 . september.

\section{LEVE}

Landsforeningen for etterlatte ved selvmord

For mer informasjon om Verden sdagen for selvmordsforebygging, ta kontakt med prosjektleder G ry Lunde i LEV Es sekretariat på tlf. 22502570 / 41140559 eller e-post: post@leve.no / www.leve.no sjons- og billedkunst. U tstillingen ble sett av

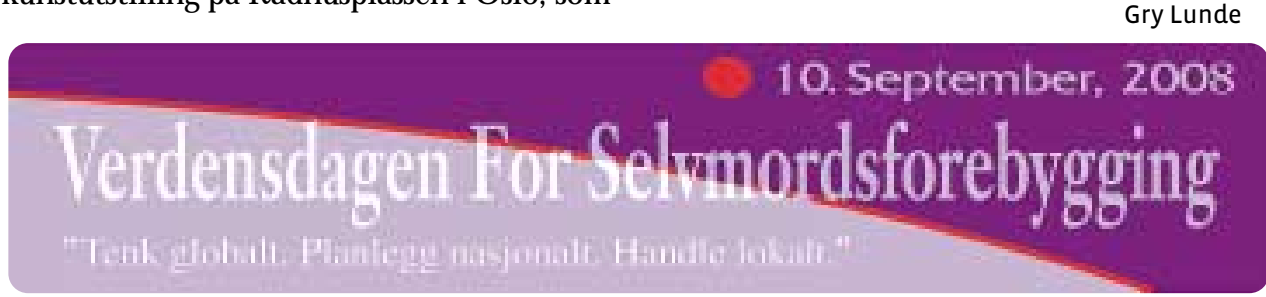

